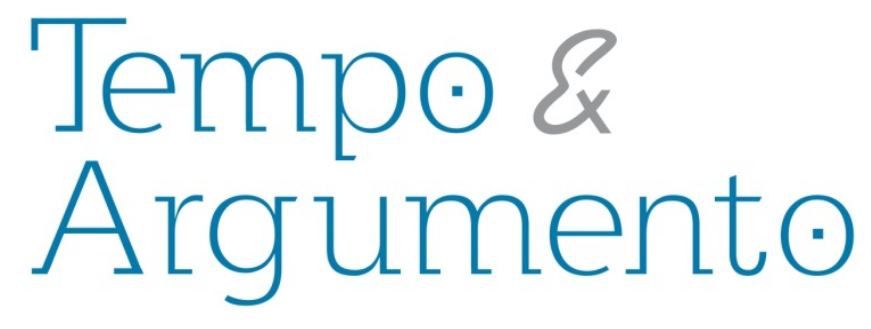

\title{
A jornada mitológica de Mário Palmério
}

\section{Resenha da obra:}

FONSECA, André Azevedo da. A construção do mito Mário Palmério: um estudo sobre a ascensão social e política do autor de Vila dos Confins. São Paulo: Editora UNESP, 2012.

\section{Autora:}

\section{Adgélzira Capeloti Pereira}

Mestranda em Comunicação Visual pela Universidade Estadual de Londrina - UEL. Especialista em Docência no Ensino Superior, pela Universidade de Maringá - Cesumar e especialista em Semiótica e Produção de Textos, pela Universidade do Oeste Paulista. Graduada em Comunicação Social, com habilitação em Jornalismo, pela Unoeste de Presidente Prudente Brasil dicapelotti@hotmail.com

\section{Para citar esta resenha:}

PEREIRA, Adgélzira Capeloti. A jornada mitológica de Mário Palmério. Revista Tempo e Argumento, Florianópolis, v. 6, n.12, p. 271 - 275, mai./ago. 2014. 
No livro "A construção do mito Mário Palmério: Um estudo sobre a ascensão social e política do autor de Vila dos Confins", André Azevedo da Fonseca reconstrói parte da história de Uberaba e, até mesmo, traça um panorama histórico, cultural e político do Triângulo Mineiro entre as décadas de 1940 e 1950. A obra, com 306 páginas, publicada pela Editora Unesp, em 2012, analisa as estratégias simbólicas utilizadas por Palmério na busca de prestígio pessoal, profissional e político e tem seus caminhos iluminados pela história cultural.

A publicação é resultado da tese de doutorado em do autor História, defendida na Universidade Estadual Paulista Júlio de Mesquita Filho (Unesp). Pós-doutor em Estudos Culturais no Programa Avançado de Cultura Contemporânea (PACC/UFRJ), Fonseca é especialista em História do Brasil pela Pontifícia Universidade Católica (PUC) de Minas Gerais e graduado em Comunicação Social (Jornalismo), pela Universidade de Uberaba (Uniube).

Seu currículo, cuja ênfase se encontra na interdisciplinaridade, especialmente na tétrade história, comunicação, cCultura e política, certamente contribuiu para esmiuçar e apresentar aspectos mitológicos da vida do professor e político Mário Palmério, mais conhecido como autor dos livros Vila dos Confins (1956) e Chapadão do Bugre (1965), ambas relevantes para a literatura brasileira.

Vale ressaltar que Palmério foi sucessor de Guimarães Rosa na Academia Brasileira de Letras, em que foi o quarto ocupante da Cadeira 2, da qual tomou posse em 1968. No romance Vila dos Confins, com o qual alcançou o auge da celebridade, trata de fraudes eleitorais, área por ele muito conhecida. Já a segunda obra, Chapadão do Bugre, também romance, apresenta costumes regionais e uma narrativa mitológica que conduz ao seu universo particular.

Fonseca, no entanto, deixa claro que não é a contribuição literária de Palmério seu foco de pesquisa, mas as ferramentas que o político utilizou com maestria na área simbólica, conseguindo, dessa forma, atingir o imaginário da população do interior de Minas Gerais, sagrando-se como bom filho, educador dedicado, empreendedor bem-sucedido e político preparado para entender os anseios do povo e a eles atender.

Considerado por Fonseca um significativo exemplar de "ator político". Sua pesquisa mostra que Palmério teatralizou uma imagem pública, conquistou distinção social e se 
legitimou como portador das aspirações populares da época, até consagrar-se como "verdadeiro mito da cultura política regional".

Para apresentar toda a trajetória mitológica enfrentada pelo herói mineiro, Fonseca divide o livro em dois atos, mais uma conclusão. No primeiro - Mário Palmério na escalada do reconhecimento social -, são abordados temas como o prestígio que sua família gozava na sociedade uberabense, sua socialização, sua incrível ascensão profissional e sua consagração pública.

Ao mostrar o destaque conquistado pela família de Palmério em Minas Gerais, mais especificamente na sociedade uberabense, Fonseca situa o ambiente em que o escritor, caçula de uma grande família, "numerosa e tradicional”, nasceu e cresceu, atento aos costumes e meandros de uma sociedade cujos membros sempre se empenharam em conquistar o poder e nele permanecer.

O segundo ato - A consagração do mito -, compreende uma revisita do autor à trajetória profissional de Palmério, com análise metodológica que demonstra que, mudando a forma de indagar, novos dados são revelados ao leitor. Neste momento da pesquisa, apresenta um estudo sobre o contexto local no período pós-guerra, no qual situa a ascensão política de Palmério na sociedade.

Ainda sobre o pós-guerra, são abordadas, amarradas e bem situadas a crise social, econômica, política, identitária, alémdo ideal do separatismo do Triângulo Mineiro do estado de Minas Gerais. Nesse ato, apresenta também o anúncio do herói e sua saga, composta pela jornada do mito Mário Palmério, a conspiração que enfrentou, e seu triunfo. As ideias de Fonseca vão se desencadeando de forma latente e agradável e mostram um Palmério que mais se parece com um personagem de seus livros literários.

Como pesquisador, é possível perceber a preocupação de Fonseca em comprovar os fatos que apresenta. A utilização de imagens cedidas pela família, assim como de impressos da época e de outras diferentes fontes documentais são recorrentes na obra. A busca por materiais visa a embasar a tese de que Palmério soube manejar com grande habilidade sua propaganda pessoal e os códigos de prestígio em circulação na cidade, de forma a traçar e encaminhar sua trajetória, conscientemente, rumo aos seus objetivos e ao êxito. 
Para tanto, Fonseca utiliza conceitos da imaginação social de Bronislaw Baczko e da teatrocracia, proposta por George Balandier, para defender que, para atribuir sentido ao mundo, de maneira que os favoreça, os atores políticos fundam uma sociedade política organizada a partir das regras do teatro. Segundo o autor, é preciso dominar as ideias sobre o teatro para entender a política, tendo em vista que, ao se dizer que os políticos dramatizam e encenam, não se estão utilizando metáforas.

Outro referencial teórico sobre o qual Fonseca se apoia é a pesquisa com a qual Erving Goffman esmiuça o papel dos atores sociais e defende que a representação social e a disputa por aplausos não ocorrem apenas no campo da vaidade. Também evoca a obra de Pierre Bordier no tocante ao poder simbólico, que faz com que a integração social seja real para quem está "por cima" e fictícia para os demais, que obedecem às regras. É a legitimação da dominação, de forma consciente e inconsciente, de maneira reproduzida, repetida, copiada.

Por último, Fonseca cita Jean Starobinski para tratar da construção literária da realidade, com a qual se substitui a virtude pela 'máscara da virtude'. A autor mostra que a situação vivida em Uberaba era uma ficção consentida. No teatro encenado, a elite era respeitada e teve em Palmério um dos maiores e principais atores sociais e políticos de sua época.

Enfim, ao procurar preencher uma lacuna pela ausência de trabalhos que analisassem as condições históricas regionais que favoreceram a emergência de um líder político com as características reunidas por Mário Palmério, Fonseca mergulha em águas mitológicas. No entanto, apesar de todo caráter científico, com forte embasamento teórico, que demonstra a construção consciente de um mito, a obra é agradável, beirando a ficção; aliás, uma invenção fabulosa que bem se assemelha à vida de Palmério ou à de um de seus personagens.

\section{Referências}

FONSECA, André Azevedo da. A construção do mito Mário Palmério: um estudo sobre a ascensão social e política do autor de Vila dos Confins. São Paulo: Editora Unesp, 2012. 
Recebido em: 13/05/2014 Aprovado em: 03/07/2014

Universidade do Estado de Santa Catarina - UDESC Programa de Pós-Graduação em História - PPGH

Revista Tempo e Argumento Volume 06 - Número 12 - Ano 2014 tempoeargumento@gmail.com 